\title{
Evaluating Two Systems of Poultry Production: Conventional and Free-Range
}

\section{Author(s)}

Lima AMC

Nääs $\mid A^{2}$

Veterinarian, Graduate student, Agricultural Engineering College, UNICAMP

2 Professor, Agricultural Engineering College, UNICAMP. irenilza@agr.unicamp.br

\section{Mail Address}

Irenilza de Alencar Nääs

Fenagri - Unicamp

Caixa Postal 6011 - Cidade Universitária

13083-970. Campinas, SP, Brasil

E-mail: irenilza@agr.unicamp.br

\section{ABSTRACT}

The improvement in production technology was the major factor that lead Brazil to become the third largest poultry producer. The improvement was world's based on the careful control of several aspects, including which nutrition and management (environment, health and rearing systems). Nowadays, the search for good welfare conditions is a global tendency in animal production. Concomitantly, an extensive production system of free-range broilers has been increasing in Brazil. This study evaluated in situ production indexes of two different commercial broiler productions, an intensive and conventional (farm A) and a semi-extensive free-range production (farm B), in order to assess the relationship between productivity and management. It was observed that the physical environment in farm A presented higher temperatures and relative humidity. Based on the results, the production index was better in farm A than in farm B. It was not clear that the production index was related to inadequate welfare of broilers under the conventional rearing system.

\section{INTRODUCTION}

Free-range broiler production has increased substantially as a result of the greater demand for the so-called natural products (Silva et al., 2001; Dawkins et al., 2003). This rural activity may represent a profitable alternative for small producers and may offer better broiler welfare as well (Bastianelli, 2001; Heier et al., 2002; Mclnerney, 2004).

Naked-neck broilers with red feathers (Label Rouge ${ }^{\circledR}$ ) have been used in free-range production in Brazil. These birds are more resistant to heat stress when compared to fully-feathered breeds (Silva et al., 2001) as they dissipate sensible heat more efficiently through the naked areas of the body (Singh et al., 2001; Hellmeister Filho et al., 2003).

Bird density in conventional broiler rearing systems directly affects productive indexes as well as bird welfare (Bolis, 2001; Maddocks et al., 2001; Garcia et al., 2002).

There is no clear definition of the best rearing conditions for freerange production in Brazil. Besides, the productive indexes are rather conflicting when compared to conventional production.

The objective of this research was to evaluate productive indexes in two systems of broiler rearing: conventional (totally confined) and freerange (partially confined).

\section{Methodology}

The research was carried out in two broiler production farms in the region of Anhembi, SP, latitude $22^{\circ} 45^{\prime}$ South, longitude $48^{\circ} 10^{\prime}$ West and altitude of $500 \mathrm{~m}$. The weather in the region shows predominantly hot and humid summer and moderate cold and dry winter, with average 
annual temperature of $20.9^{\circ} \mathrm{C}$ and rain index of 1,230 $\mathrm{mm}$. The data of regional temperature, relative humidity and rain index were collected at the meteorological station Posto Agrometeorológico da Área de Física e Meteorologia - LCE, at Escola Superior de Agricultura - ESALQ (USP), located in Piracicaba County, SP, Brazil, at a latitude 22 $42^{\prime} 30^{\prime \prime}$ South, longitude $47^{\circ} 38^{\prime} 00^{\prime \prime}$ West and altitude of $546 \mathrm{~m}$.

The water content of the bedding material (litter humidity) was analyzed at Faculdade de Engenharia Agrícola da Unicamp (FEAGRI). The assessment of the general management of both farms was done in a descriptive way through visual observation. The total period of studying and observation was from November 5th, 2004 to March 15th, 2005.

Both farms were integrated to the same company and the birds were slaughtered in an abattoir with Federal Inspection (SIF) located $74 \mathrm{~km}$ from the farms in Pereiras County, SP.

In the conventional housing system (farm A), Cobb ${ }^{\circledR} /$ $\mathrm{Hybro}^{\circledR}$ birds were used. The birds were slaughtered at 45 days of age with an average weight of $2.5 \mathrm{~kg}$. A sex-mixed flock of 14,000 one-day-old chicks was reared in a concrete-floored poultry house measuring $100 \mathrm{~m} \times 10 \mathrm{~m}$ and height of $2.8 \mathrm{~m}$, East-West oriented and naturally ventilated with side and roof openings. The roof was covered with white-coated fiber cement tiles. Side walls height measured $0.6 \mathrm{~m}$, and wire mesh side openings were covered with yellow plastic curtains. Nipple-type drinkers and tray feeders were initially used; tray feeders were replaced by automatic feeders after three weeks. Initial density was $65-80$ chicks $/ \mathrm{m}^{2}$ and was decreased until 14 broilers $/ \mathrm{m}^{2}$ by the end of the growing period. During the initial growing period the chicks were placed inside cardboard brooding circles and heating was provided by gas heaters. The house was equipped with twenty $0.5 \mathrm{HP}$ fans placed at every $10 \mathrm{~m}$ and $2.0 \mathrm{~m}$ above the floor, and the fogging system along the house had two lines of nozzles at every $10 \mathrm{~m}$. Wood shavings were used as bedding material. The diet was based on maize $(60.7 \%)$, soybean meal $(35.3 \%)$, dicalcium phosphate (2.2), limestone $(0.9 \%)$, sodium chloride $(0.4 \%)$, mineral/vitamin supplement $(0.5 \%)^{1}$, crude protein $(20.5 \%)$, metabolized energy $(2880 \mathrm{kcal} / \mathrm{kg})$, calcium

Provided per kg: Vit. A, 2,500,000 IU; Vit. D3, 500,000 IU; Vit. E, 3,500mg; Vit. K, 600mg; Vit. B1, 150mg; Vit. B2, 1,200mg; calcium pantothenate, 3,000mg; niacin, 8,500mg; Vit. B12, 3,000mcg; biotin, 10mg; choline chloride 50\%, 150,000mg; folic acid, 100mg; Co, 40mg; Cu, 3,000mg; Fe, 25,000mg; Mg, 26,000mg; Se, 100mg; Zn, 18,000mg; DL-methionine, 200,000 mg; antioxidant, 2,000mg.
(0.97\%), and available phosphorus $(0.49 \%)$, according to the nutritional requirements suggested by the integrator. A growth promoter $(12,500 \mathrm{mg})$ and a coccidiostat $(15,000 \mathrm{mg})$ were added to the growing diet. The nutritional program was divided into four phases as follows: pre-initial (1-7 days old); initial (8$21 \mathrm{~d})$, growing (22-38 d); and final (39-45 d).

Label Rouge ${ }^{\circledR}$ birds were reared in the free-range system (farm B) and were slaughtered at 80 days of age with mean body weight of $2.0 \mathrm{~kg}$. A sex-mixed flock of 7,150 one-day-old chicks was reared in a house measuring $51 \mathrm{~m} \times 12 \mathrm{~m}$, and height of $2.0 \mathrm{~m}$. The house was East-West oriented, with compacted soil floor and naturally ventilated with side and roof openings. Clay tiles covered the roof and wood shavings were used as bedding material. Side walls measured $0.5 \mathrm{~m}$ and wire mesh side openings were covered with blue plastic curtains. In the first three weeks, heating was provided by three wood burning stoves. The cardboard brooding circles were gradually opened to provide more floor space and bird density was decreased from 65-80 birds $/ \mathrm{m}^{2}$ to 11 birds $/ \mathrm{m}^{2}$ after two weeks. The birds had access to an open area (pasture) of approximately $3,200 \mathrm{~m}^{2}(100 \mathrm{~m} \times 32 \mathrm{~m})$ after 30 days of age. The area was naturally shaded by Caruru bushes during most of the day. Free access to pasture was provided 10$12 \mathrm{~h} /$ day and the birds were placed inside the house at dusk, where they were kept until the next morning. Bell-type drinkers and initial tray feeders were used; feeders were changed at three weeks of age to larger manual feeders. The paddocks had no drinkers or feeders. Diets were similar to those fed to conventionally-reared broilers, except that there was no addition of antibiotics or other chemical additives or components. The nutritional program was divided into four phases according to the bird age as follows: pre-initial (1-7 d); initial (8-31 d), growing (32-50 d); and final (51-80 d).

Harvesting and transportation procedures from the farm to the abattoir were similar for both flocks.

Environmental data (regional ambient temperature in degrees centigrade and relative humidity in percentage) were collected using four $\mathrm{HOBO}^{\circledR} \mathrm{H} 8$ data loggers. Readings were recorded at every $90 \mathrm{~min}$ at the geometric center of the building during the growth period.

The equations described by Dawkins et al. (2003) were used to calculate the habitat/ambient use of the area in farm $B$, and the birds were filmed for $15 \mathrm{~min}$ at 15,45 , and 75 days of age, both inside the house (close to the door) and in the pasture (under a tree shade), 
focusing on the birds moving out of the house. The recording started only after a 15-min adaptation period, so that the birds would be adapted to the presence of the researcher.

Equation 1 was used to calculate the variation in the use of the habitat and to estimate bird density in relation to the different use of the areas (inside the house and under the shade of bushes and trees).

$$
v=\frac{\sum_{i}\left(w_{i} * b_{i}^{2}\right)-\left[\sum_{i}\left(w_{i} * b_{i}\right)^{2} / \sum_{i}\left(w_{i}\right)\right.}{\sum_{i}\left(w_{i}\right)} \quad \text { Equation } 1
$$

where $v$ is the average variation (use of distinct types of habitats) described by the coefficient of variation of expected values $(w) ; i$ is the number of birds in the pasture; $w_{i}$ is the number of birds observed in a certain area; $b$ is the reference density $\left(b_{i}=1\right)$; and $\sum_{i}$ is the total number of considered habitats. The values of $w$ were calculated using Equation 2.

$$
w_{i}=\sum_{n}\left[\frac{a_{i}^{*} F}{A}\right]
$$

Equation 2

where $a_{i}$ is the area occupied by the bird $i$ in the pasture area; $A$ is the total pasture area; and $F$ is the total number of birds in the pasture area. The value $\sum_{n}$ is the total area occupied by the birds. In this research, the total occupancy area (house + pasture) was considered $100 \%$.

The water content in the bedding material (litter humidity) was assessed using three samples taken from each farm in the last week of rearing. The samples were put into plastic bags and, after removing the air, the bags were hermetically closed and taken to the Faculdade de Engenharia Agrícola da UNICAMP (FEAGRI) under refrigeration. The analysis was performed according to BRASIL (1992). Means of the three samples were calculated and expressed as percentages.

The following productivity indexes were assessed: mortality (M, Equation 3); daily weight gain (DWG, Equation 4); feed consumption; and feed conversion (FC, Equation 5); feasibility (F) and production index (PI, Equation 6), as defined by Araújo et al. (2002), Stringhini et al. (2003) and Hellmeister Filho et al. (2003).
$M(\%)=$ (number of dead birds/number of one-dayold chiks) $\times 100$

Equation 3

DWG $(\mathrm{kg} /$ day $)=$ mean weight at slaughter $(\mathrm{kg}) /$ days at slaughter

Equation 4

$\mathrm{FC}=$ total feed intake $(\mathrm{kg}) /$ total body weight $(\mathrm{kg})$

Equation 5

$P I=(D W G . F) / F C \times 100$

Equation 6

Mortality percentage was calculated taking into account the dead birds from the first day of rearing. Average weight gain was obtained dividing total live weight by the number of harvested birds. Mean feed intake was calculated dividing the total feed intake by the number of harvested birds.

Feasibility was calculated dividing the number of harvested broilers by the number of live birds arriving at the abattoir, multiplied by 100 and expressed as percentage.

Mean feed intake was calculated dividing the total feed intake during production by the total number of birds. A sample of 20 birds was randomly chosen in both farms and the average weight at slaughter was calculated one day before the slaughter.

Flock uniformity in both farms was assessed both directly and indirectly. Direct assessment was performed using the video image of 375 carcasses that were filmed for three periods of 1 min (speed of slaughter 7,500 bird/h). Indirect evaluation was performed using equipment records and machinery logbooks in regard to the necessity of adjustments during slaughter.

The general management history of six flocks from the conventional farm and four flocks from the freerange broiler system were used for comparison and in order to help to understand the statistical analysis. A descriptive analysis of the data was done. On the slaughter day, the total weight of birds was recorded. Data were statistically analyzed using Student's t test, and boxplot graphs were built using Minitab ${ }^{\circledR}$.

\section{RESULTS AND DISCUSSION}

Table 1 presents the summarized mean data of ambient temperature, relative humidity and litter humidity.

Ambient temperature inside the houses was significantly different between farms $A$ (conventional) and $B$ (free-range) $(p<0.0001)$. Figure 1 shows the ambient temperature pattern. Average values were $25.15^{\circ} \mathrm{C}$ in farm $\mathrm{A}$ and $26.25^{\circ} \mathrm{C}$ in farm B. Farm A had an effective high temperature control and the 
occurrence of large amplitudes during the day was limited, as recommended by Tinôco (1995), Nääs et al. (1998) and Moura (2001).

\begin{tabular}{lll}
\hline Table 1 - Environmental variables in two systems of broiler rearing: \\
conventional (farm A) and free-range (farm B). \\
\cline { 2 - 3 } Environmental variables & \multicolumn{2}{c}{ Farm } \\
\cline { 2 - 3 } & A (conventional) & B (free-range) \\
Mean temperature $\left({ }^{\circ} \mathrm{C}\right)$ & $25.15^{\mathrm{a}}(\mathrm{n}=781)$ & $26.25^{\mathrm{b}}(\mathrm{n}=1216)$ \\
Mean relative humidity $(\%)$ & $66.80^{\mathrm{a}}(\mathrm{n}=781)$ & $64.90^{\mathrm{a}}(\mathrm{n}=1216)$ \\
Litter humidity $(\%)$ & $64.00^{\mathrm{a}}(\mathrm{n}=3)$ & $28.80^{\mathrm{b}}(\mathrm{n}=3)$ \\
\hline
\end{tabular}

Means followed by different letters in the row are different $(p<0.05)$.

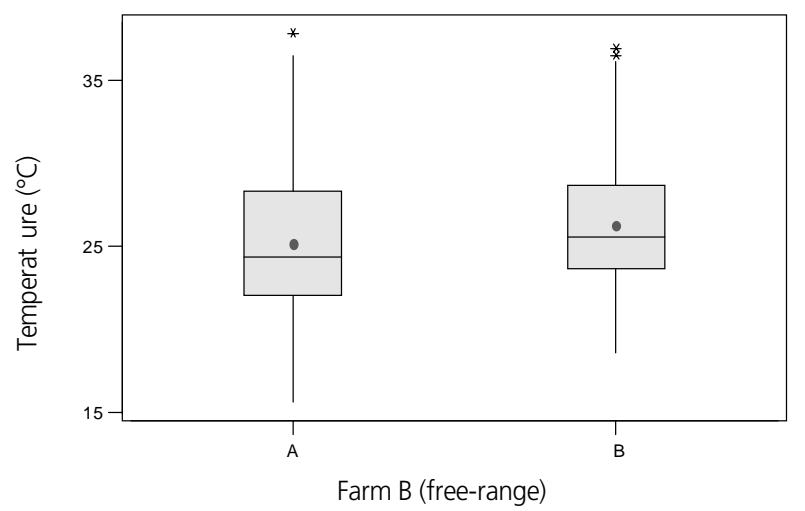

Figure 1 - Environmental temperature inside the houses in two different systems of broiler production: conventional (farm A) and free-range (farm B).

The high mean temperature observed in farm B was expected, since neither fan nor evaporative cooling systems were used. The mean temperature could have been even higher if the broilers had been kept inside the house rather than outside in the pasture. The difference between inside and outside temperature was also statistically significant $(p<0.001)$. Since the outside temperature $\left(22.89^{\circ} \mathrm{C}\right.$ ) was lower than inside temperature $\left(25.85^{\circ} \mathrm{C}\right)$, the birds spent most of the day in the pasture (Figure 2). House temperatures in farm A (conventional) and farm B (free-range) were similar in numbers, but were statistically different $(p<0.001)$.

Mean litter humidity was $64 \%$. Such value is considered high (Paganini, 2004) and may have influenced the productive indexes as proposed by McFerran (1993). According to Mendes (2001), the structure of the bedding material may cause lesions and losses in broiler production. Litter humidity was $29.8 \%$ in farm B, probably due to the low bird density during the daytime $\left(<11 \mathrm{birds} / \mathrm{m}^{2}\right)$. Figure 3 shows the mean litter humidity in both farms $(p<0.05)$

The broilers barely moved in farm A (conventional), whereas the density in farm B (free-range) was 11 birds $/ \mathrm{m}^{2}$ until 30 days of age. The habitat/environment use (Dawkins et al., 2003) was assessed and it was estimated that $80 \%$ of broilers preferred to stay in the pasture even during the winter, while the remaining $20 \%$ stayed inside the house.

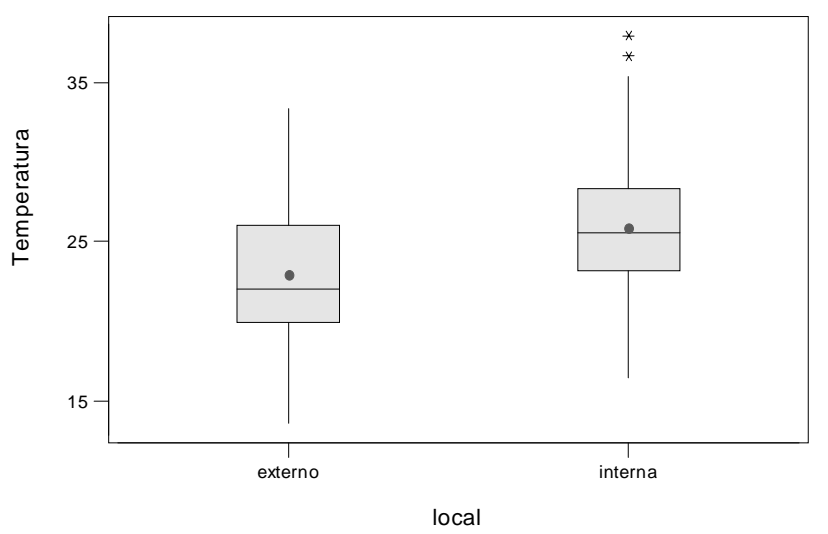

Figure 2 - Mean temperature inside and outside the house in farm $B$ (free-range).

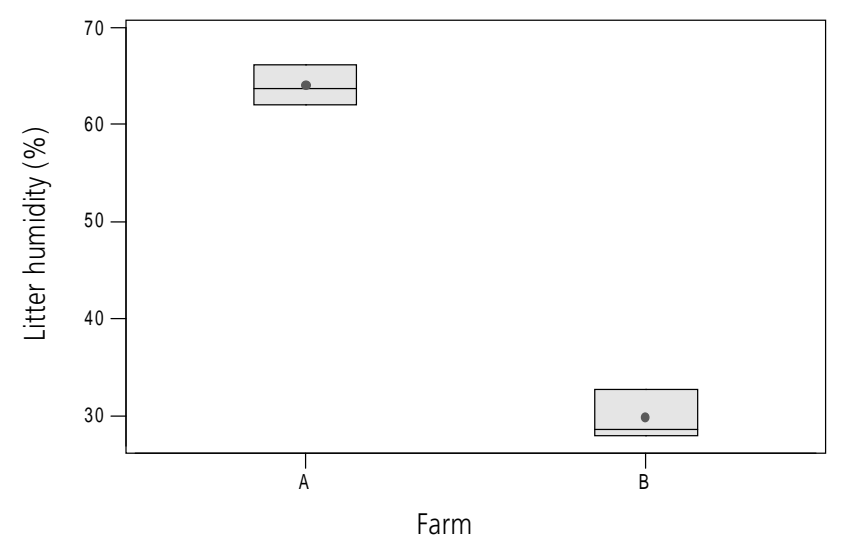

Figure 3 - Litter humidity (\%) in rearing systems A (conventional) and $B$ (free-range).

Means of the production parameters are shown in Table 2 (mortality, average weight at slaughter and feed conversion, etc).

\begin{tabular}{lcc}
\hline \multirow{2}{*}{$\begin{array}{l}\text { Table } \mathbf{2} \text { - Mean productive indexes in farms A and B (conventional } \\
\text { and free-range rearing). } \\
\text { Productive index }\end{array}$} & \multicolumn{2}{c}{ Farm } \\
\cline { 2 - 3 } & A (conventional) & B (free-range) \\
Mortality (\%) & $5.32^{\mathrm{a}}$ & $1.34^{\mathrm{b}}$ \\
Final body weight (kg) & $2.58^{\mathrm{a}}$ & $2.10^{\mathrm{b}}$ \\
Feed conversion & $1.97^{\mathrm{a}}$ & $2.98^{\mathrm{b}}$ \\
Age at slaughter (days) & 45 & 80 \\
\hline
\end{tabular}

Means followed by different letters in the row are different $(p<0.05)$ Farm A ( $n=6$ flocks); Farm B ( $n=4$ flocks).

Table 3 presents the results of productive index (PI), daily weight gain (DWG) and feed conversion (FC). 
Conventional rearing showed higher mortality (5.32\%) than free-range rearing $(1.43 \%)(p<0.001)$, agreeing with findings reported by Hellmeister Filho et al. (2003). It is well documented that mortality is influenced by several factors such as exposition to cold weather during the first three weeks, heat stress in the end of the growing period, problems in water distribution, as well as inappropriate housing and bird density (Wang \& Edens, 1998; Sorensen et al., 2000; Martrenchar et al., 2000; Heier et al., 2002; Zulkifli et al., 2003).

Table 3 - Mean production indexes in farms A (conventional) and B (free-range).

\begin{tabular}{lcc} 
& \multicolumn{3}{c}{ Farm } \\
\cline { 2 - 3 } Production indexes & A (conventional) & B (free-range) \\
Feed intake* & 4.730 & 6.020 \\
Production index (PI)** & 2.702 & 0.833 \\
Daily weight gain (DWG, kg) & 0.056 & 0.025 \\
\hline Farm A ( $\mathrm{n}=6$ flocks); Farm B ( $\mathrm{n}=4$ flocks) & \\
${ }^{*} \mathrm{FC}=$ total feed intake $(\mathrm{kg}) /$ total body weight (kg) & (Equation 5) \\
$* * \mathrm{PI}=(\mathrm{DWG}$. F)/FC. 100 & (Equation 6)
\end{tabular}

Feed conversion (FC) was 1.97 and 2.98 in farms $A$ and $B$, respectively. Conventionally-reared broilers had better feed conversion than broilers in farm $B$ (freerange) $(p=0.001)$ as shown in Figure 4 . Hellmeister Filho et al. (2003) reported similar results in free-range Label Rouge ${ }^{\circledR}$.

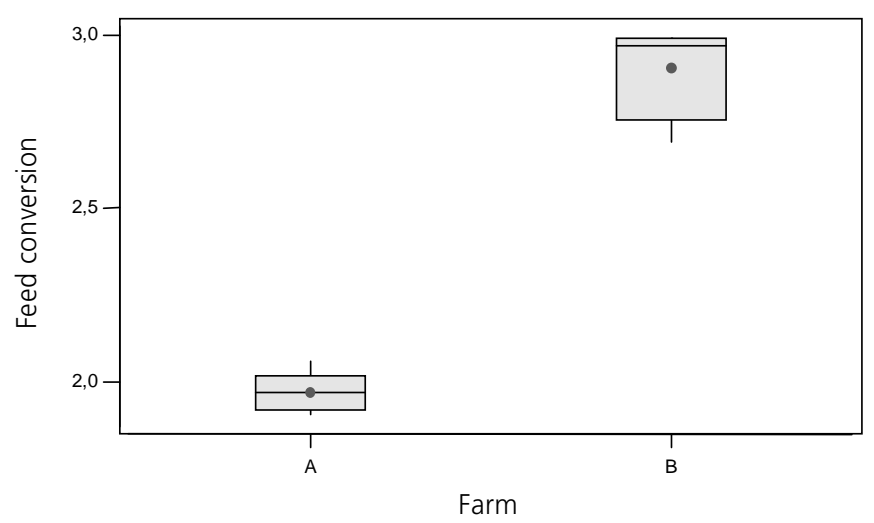

Figure 4 - Feed conversion of broilers reared in farms A (conventional) and $B$ (free-range).

Daily weight gain (DWG) was $0.056 \mathrm{~kg} /$ day for the birds from farm $A$, whereas broilers reared in the freerange system (farm B) gained $0.0252 \mathrm{~kg} /$ day. The productive index (PI) was 2.7022 in farm $\mathrm{A}$ and 0.833 in farm B. Mean feed intake was $4.74 \mathrm{~kg} /$ day in farm $A$ and $6.02 \mathrm{~kg} /$ day in farm $B$, and similar results were found by Hellmeister Filho et al. (2003).
No differences were found in carcass uniformity using the direct descriptive analysis. Besides, no modifications were needed in the machinery during slaughter, which indicates that carcasses were uniform between the farms (Mendes, 2001).

\section{CONCLUSION}

Conventional rearing in farm A presented higher broiler mortality when compared to free-range rearing in farm B. Feed conversion in the free-range system was poorer than in farm A, and both strains followed the expected genetic pattern when exposed to the housing environment. Based on the results, the production index was better in farm A than in farm B. Nevertheless, it was not clear if the production index was related to inadequate welfare of broilers under the conventional rearing system.

\section{REFERENCES}

Araújo CSS, Artoni SMB, Araújo LF, Junqueira OM, Borges SA. Desempenho, rendimento de carcaça e excreção de cálcio de frangos de corte alimentados com diferentes níveis de aminoácidos e cálcio no período de 22 a 42 dias de idade. Revista Brasileira de Zootecnia 2002; 31(6):2209-2215

Bastianelli D. A produção de frangos diferenciados na França (Mercado, aspectos organizacionais e regulamentares). In: Anais da Conferência APINCO de Ciência e Tecnologia Avícola; 2001; Campinas, SP. Campinas: FACTA, 2001. p.235-254.

Bolis D.A. Biosseguridade na criação alternativa de frangos. In: Anais da Conferência APINCO de Ciência e Tecnologia Avícola; 2001; Campinas, SP. Campinas: FACTA, 2001. p.223-224.

BRASIL. Ministério da Agricultura e Reforma Agrária. Regras para análise da qualidade e produtividade. Brasília; 1992.

Dawkins MS, Cook PA, Whittingham MJ, Mansell KA, Harper AE. What makes free-range broiler chickens range? In situ measurement of habitat preference. Animal Behaviour 2003; 65:01-10.

Garcia RG, Mendes AA, Garcia EA, Nääs IA, Moreira J, Almeida ICL, Takita TS. Efeito da densidade de criação e do sexo sobre o empenamento, incidência de lesões na carcaça e qualidade da carne de peito de frangos de corte. Revista Brasileira de Ciência Avícola 2002: 4(1):1- 9 .

Heier BT, Hogasen HR, Jarp J. Factors associated with mortality in Norwegian broiler flocks. Preventive Veterinary Medicine 2002; 53(1-2):147-158

Hellmeister Filho P, Menten JFM, Silva MAN, Coelho AAD, Savino VJM. Efeito de genótipo e do sistema de criação sobre o desempenho de frangos tipo caipira. Revista Brasileira de Zootecnia 2003: 32(6 suppl.2):1883-1889. 
Maddocks SA, Cuthill IC, Goldsmith AR, Sherwin CM. Behavioural and physiological effects of absence of ultraviolet wavelengths for domestic chicks. Animal Behaviour 2001; 62:1013-1019.

Martrenchar A, Hunnic D, Cotte JP, Boilletot E, Morisse JP. Influence of stocking density, artificial dusk and group size on the perching behaviour of broilers. British Poultry Science 2000; 41:125-130.

McFerran JB. Wet litter and enterovirus. In: Proceedings of the Solvay Chicken Health Course Held, 151., 1993. New Zealand: Massey University; 1993. p.39-44. CD Rom.

Mclnerney J. Animal welfare, economics and policy: report on a study undertaken for the farm \& animal health economics. Londres: Division of DEFRA; 2004. 68p.

Mendes AA. Rendimento e qualidade da carcaça de frangos de corte. In: Anais da Conferência APINCO de Ciência e Tecnologia Avícola; 2001; Campinas, SP. Campinas: FACTA; 2001. p. 79-99.

Moura DJ. Ambiência na avicultura de corte. In: SILVA, I.J.O. Ambiência na produção de aves em clima tropical. Piracicaba: FUNEP; 2001. p. 75-149.

Nääs IA, Magalhães E, Corria MEA. Environmental Thermohygrometric Characteristics of Poultry Housed Under High Bird Density. In: Proceedings of the Euro AgEng; 1998; Oslo. CD-Rom.

Paganini FJ. Manejo da cama. In: Mendes AA, Nääs IA, Macari M. Produção de frangos de corte. Campinas: FACTA; 2004. p107-116.

Silva MAN, Silva IJO, Piedade SMS. Resistance to heat stress of naked neck broilers. Revista Brasileira de Ciência Avícola 2001; 3 (1):27-33.

Singh CV, Kumar D, Singh YP. Potential usefulness of plumage reducing Naked Neck $(\mathrm{Na})$ gene in poultry production at normal and high ambient temperatures. World's Poultry Science Journal 2001; 57(2):127-156.

Sorensen P, Su G, Kestin SC. Effects of age and stocking density on leg weakness in broiler chickens. Poultry Science 2000; 79:864870 .

Stringhini JH, Laboissiére M, Muramatsu K, Leandro NSM, Café, MB. Avaliação do desempenho e rendimento de carcaça de quatro linhagens de frangos de corte criadas em Goiás. Revista Brasileira de Zootecnia 2003; 32(1):183-190.

Tinôco IFF. Estresse calórico: meios naturais de condicionamento. In: Anais do Simpósio Internacional sobre Ambiência e Instalação na Avicultura Industrial; 1995; Campinas. p.99-108.

Wang S, Edens FW. Heat conditioning induces heat shock proteins in broiler chickens and turkey poults. Poultry Science 1998; 77:16361645.

Zulkifli I, Liewa PK, Israfb DA, Omarc AR, Hair-Bejoc M. Effects of early age feed restriction and heat conditioning on heterophil/ lymphocyte ratios, heat shock protein 70 expression and body temperature of heat-stressed broiler chickens. Journal of Thermal Biology 2003; 28:217-222. 